\title{
NEWLY DIAGNOSED DIABETES MELLITUS IN BIHOR COUNTY BETWEEN 2016 AND 2017 DEMOGRAPHIC INDICATORS, CLASSIFICATION, COMPLICATIONS, CARDIO METABOLIC RISK FACTORS AND TREATMENT
}

\author{
Vesa Cosmin Mihai ${ }^{1,2}$, Popa Loredana ${ }^{1}$, Dana Zaha ${ }^{1,2}$, Moisi Mădălina ${ }^{1,2}$, Jurca Claudia², \\ Tica Otilia ${ }^{1}$, \\ Popescu Mircea ${ }^{1,2}$, Popa Amorin Remus ${ }^{1,2}$ \\ 1. Clinical County Emergency Hospital of Oradea, Correspondent author: \\ v_cosmin_15@yahoo.com \\ 2. Faculty of Medicine and Pharmacy of Oradea, University of Oradea
}

\begin{abstract}
Bihor is a county in north-western Romania with a population of approximately $600000^{(5)}$. One study performed at the beginning of this decade addressing diabetes epidemiology in Romania demonstrated a high prevalence of diabetes in Bihor ${ }^{(1)}$, the cause being the obesity epidemics as consequence of inadequate diet (high lipid content, refined sugars) and physical inactivity. Our study demonstrates the increasing prevalence $(4.71 \%$ in 2011 vs. 5.24\% in 2016) of diabetes in the county. Also by analyzing different epidemiological parameters we determined the profile of the newly diagnosed diabetes patient in Bihor including only the patients diagnosed in 2016 and 2017. The newly diagnosed diabetic patient is more often female than male (52.78\% vs. $47.22 \%$ ), from urban environment (51.84\% vs $48.16 \%$ ), belongs to the age group $47-65$ years (57.35\%), is obese (54.47\%) is affected by hypertension (70.65\%), dyslipidemia (72.3\%), is smoker in $23.56 \%$ of cases and sedentary in $30.50 \%$ of cases.
\end{abstract}

Keywords: diabetes epidemiology, cardiovascular risk factors in diabetes patients

\section{Rezumat}

Județul Bihor este situat în nord-vestul României având o populație de aproximativ 600000 de locuitori(5). Un studiu desfășurat la începutul acestui deceniu cu privire la epidemiologia diabetului zaharat în România a demonstrat prevalența crescută a acestuia în județul Bihor ${ }^{(1)}$, cauza fiind "epidemia" de obezitate ca o consecință a alimentației inadecvate (bogată în lipide, zaharuri rafinate) și inactivității fizice. Studiul nostru demonstrează prevalența în creștere (4.71\% în 2011 vs. 5.24\% în 2016) a diabetului în județul nostru. De asemenea prin analiza a diferiți indici epidemiologici am determinat profilul pacientului nou-diagnosticat cu 


\section{Original papers}

diabet zaharat din Bihor incluzând pacienții diagnosticați în 2016 și 2017. Acesta este mai frecvent de sex feminin decât de sex masculin (52.78\% vs. 47.22\%), din mediul urban (51.84\% vs 48.16\%), aparține grupei de vârstă 47-65 de ani (57.35\%), este obez (54.47\%), suferă de hipertensiune (70.65\%), dislipidemie (72.3\%), este fumător într-un procent $23.56 \%$ de din cazuri și sedentar într-un procent de $30.50 \%$ din cazuri.

Cuvinte cheie: epidemiologia diabetului, factori de risc cardiovasculari la pacienții diabetici.

\section{Introduction}

Diabetes Mellitus is a chronic disease that represents a public health problem. The importance of studies about newly diagnosed patients with diabetes should not be underestimated because the diagnosis of diabetes represents an important point in the patients' health history and also in the attitude of the physician towards the patient. This diagnosis means that the patient is at a higher risk of cardio-vascular disease like myocardial infarction or stroke, and he should be carefully evaluated concerning not only glycaemia, but also the presence of obesity, blood pressure, lipid metabolism, presence of microvascular and macrovascular complications, lifestyle choices, smoking, physical activity. Intensive treatment is required addressing to each of the risk factors in order to reduce the frequency or to postpone the cardiovascular clinical events.

\section{Material and Methods}

We included in the study all the patients diagnosed with diabetes mellitus in Bihor County in the year 2016 and 2017. The registration method included information about sex, age, urban or rural environment, family history of diabetes, height, weight, smoking status, presence of physical activity, presence of cardiovascular diseases in the past. adequate therapy for hyperglycaemia was determined and we also included these criteria in the patient evaluation. Data about epidemiological indicators and clinical indicators was analysed both as number and percent of the total number of patients diagnosed in each year.

\section{Results and Discussion}

The number of newly diagnosed diabetes mellitus cases in 2017 is lower than in 2016 


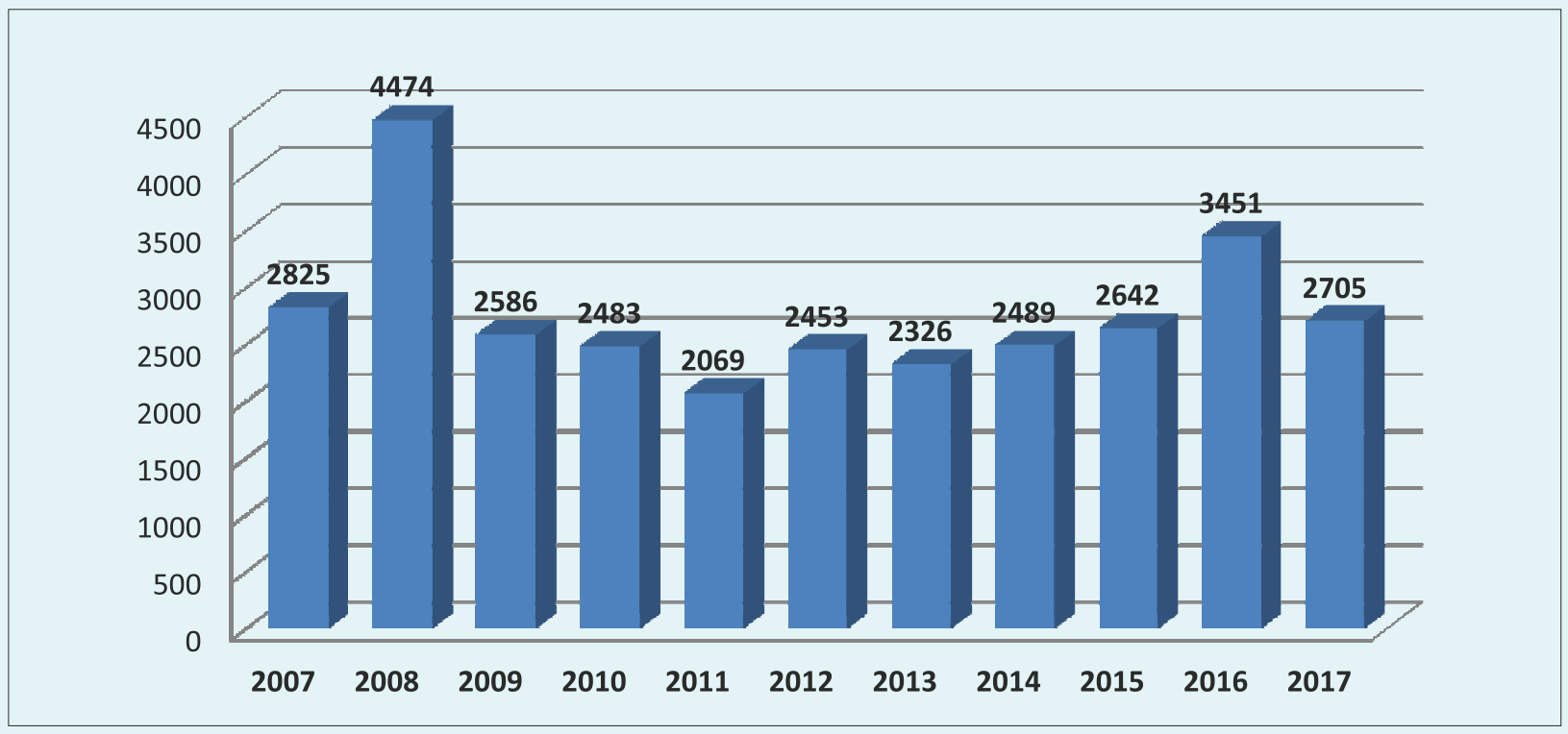

Figure nr. 1. Incidence of diabetes mellitus in Bihor County from 2007 to 2017

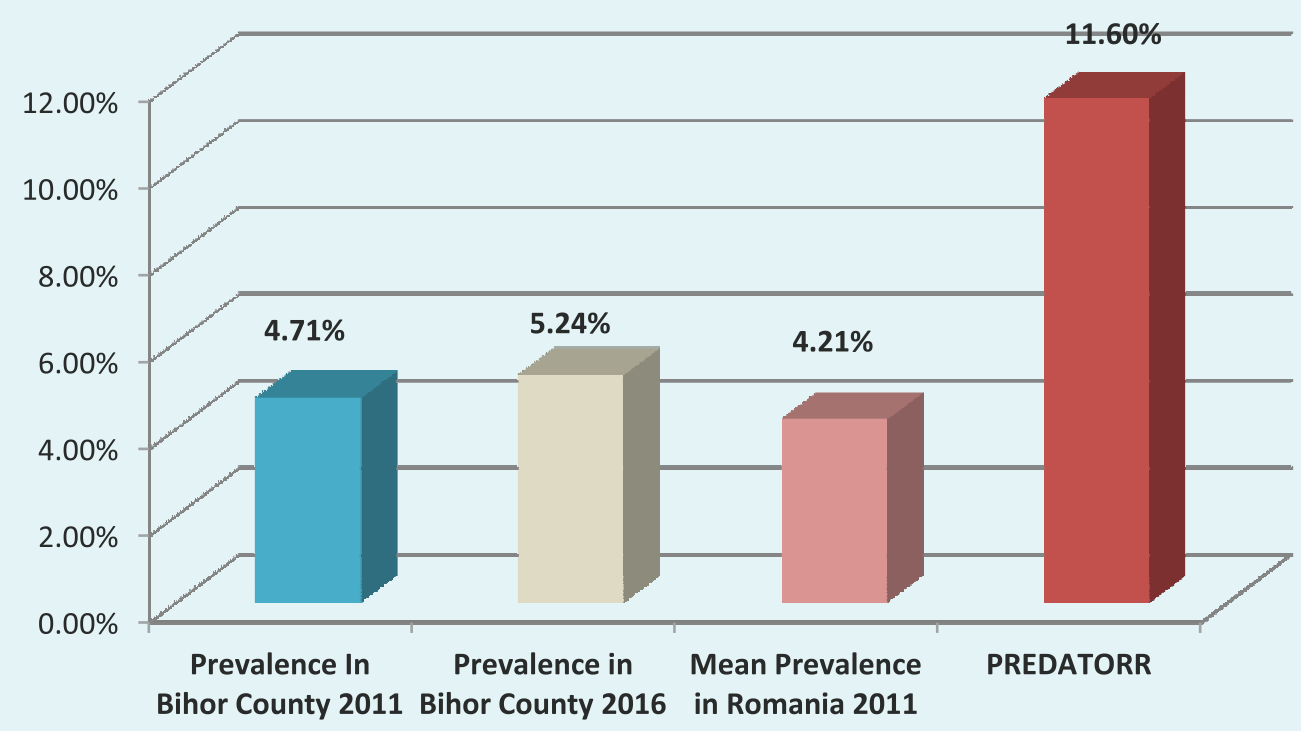

Figure nr. 2 Diabetes prevalence comparison between 2011 and 2016 in Bihor County, and with data provided by a national study in 2011 and PREDATORR study

(2705 vs. 3451), however we cannot discuss about a descending trend considering the fact that the incidence of diabetes mellitus in 2017 is comparable with the incidences from 2015, 2012 or 2009 (figure 1). The high number of patients diagnosed in 2008 could have a possible explanation, as 2008 is the year following 2007 when the National Program for Assessing Population Health took place, and a significant number of people who were diagnosed with glucose regulation abnormalities, which are common in general population, possibly continued medical investigations in the next year and were finally diagnosed with diabetes.

The prevalence of diabetes mellitus in Bihor County at the end of the year 2016 was $5.48 \%, 33907$ people having the diagnosis of diabetes out of a population of 618453 persons. Compared with the prevalence of 


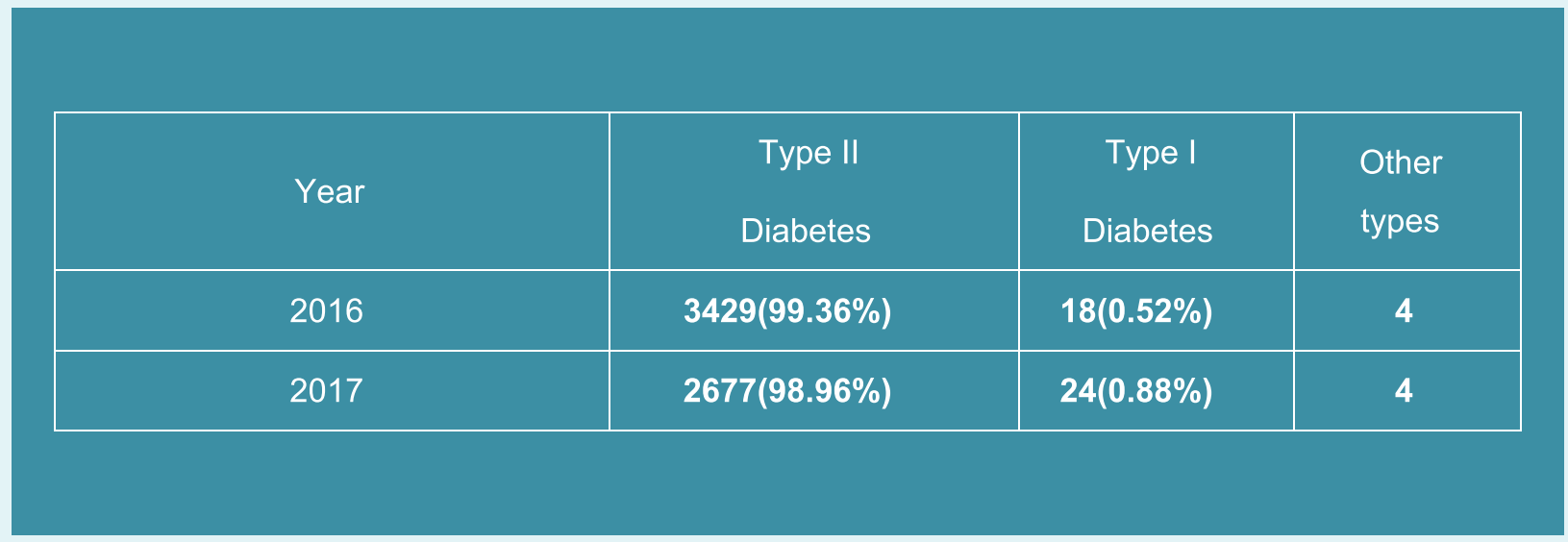

Table nr. 1. Distribution of diabetes mellitus types in 2016 and 2017

diabetes in the PREDATORR study ${ }^{(2)}$, the prevalence of the disease in Bihor County is reduced $(5.4 \%$ vs. $11.6 \%)$, however considering the complexity of the PREDATORR study and its screening purpose, a more suitable comparison would be with previous studies that made analyses on data provided by the registers from each county in Romania. One of these studies showed a mean prevalence of diabetes of $4.21 \%$ in Romania in $2011^{(1)}$, in Bihor County the prevalence being $4.71 \%$. Therefore comparing the prevalence of diabetes in Bihor County in 2016 with the prevalence in 2011 , we found an increase to $5.48 \%$ of total population in 2016 from 4.21\% in 2011 (figure 2). The PREDATORR study proved that the prevalence of diabetes in general population is approximately double than the prevalence given by the registers, in accordance with the principle that for every diagnosed patient with diabetes there is another diabetes patient undiagnosed, a rule that without doubt applies in Bihor County. Therefore it would be well-welcomed a similar study, cross-sectional, population stratified, in our county.

In Bihor County type II diabetes represents $99.36 \%$ of the total number of cases of diabetes diagnosed in 2016 and $98.86 \%$ of the total number of cases of diabetes diagnosed in 2017. The incidence of type I diabetes is reduced only $0.52 \%$ and $0.88 \%$ were diagnosed with this type of diabetes in 2016 and 2017. Considering the fact that type II diabetes appears mostly as a consequence of modern lifestyle, this data gives us the prove that modification of lifestyle could lead to a significant reduction in number of new cases 


\begin{tabular}{|c|c|c|}
\hline Year & Males & Females \\
\hline 2016 & $\mathbf{4 8 . 0 5 \% ( 1 6 5 8 )}$ & $\mathbf{5 1 . 9 5 \% ( 1 7 9 3 )}$ \\
\hline 2017 & $46.39 \%(1254)$ & $\mathbf{5 3 . 6 1 \% ( 1 4 5 1 )}$ \\
\hline $2016+2017$ & $\mathbf{4 7 . 2 2} \%$ & $\mathbf{5 2 . 7 8 \%}$ \\
\hline
\end{tabular}

Table nr.2. Cases distribution according to patients' sex

\begin{tabular}{|c|c|c|}
\hline Year & Urban & Rural \\
\hline 2016 & $52.85 \%(1823)$ & $47.15 \%(1628)$ \\
\hline 2017 & $50.84 \%(1375)$ & $49.16 \%(1329)$ \\
\hline
\end{tabular}

Table nr. 3. Patients' distribution according to residence

\begin{tabular}{|c|c|}
\hline Age & \\
\hline $1-20$ years & $0.73 \%$ \\
\hline $21-45$ years & $12.58 \%$ \\
\hline $46-65$ years & $57.35 \%$ \\
\hline$>65$ years & $29.32 \%$ \\
\hline
\end{tabular}

Table nr. 4. Patients' distribution according to age 


\section{INTERNAL MED}

\section{Original papers}

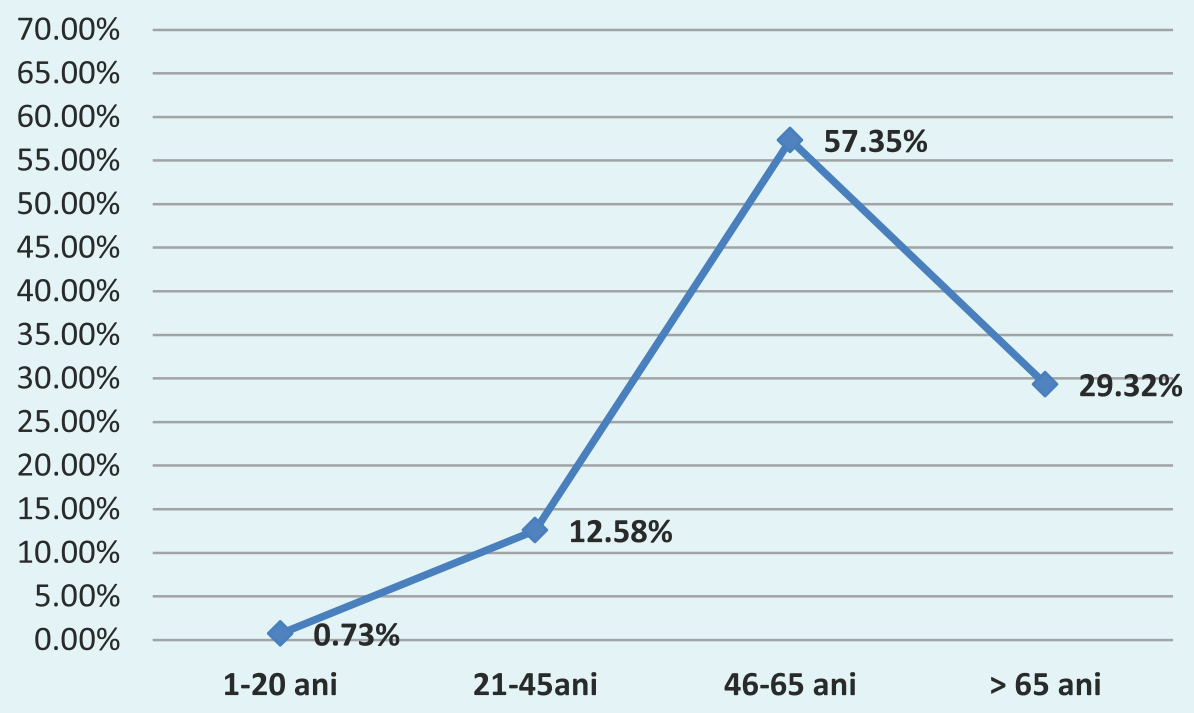

Series1

Figure. nr. 4. Percent of patients in age groups

In Bihor County diabetes appears between 2016 and 2017 appeared more frequently in females than in males ( $52.78 \%$ vs $47.22 \%$ ), a similar trend being observed in 2016 (48.05\% vs $51.95 \%)$ and 2017 (46.39\% vs $53.61 \%)$. The possible explanation for the greater incidence of diabetes in females is that females have a greater percent of total body fat tissue than males, females tend to be more obese than males with increasing $\operatorname{age}^{(3)}$, the greater vulnerability of females to psychosocial stress, a higher consumption of refined sugars and an increasing prevalence of smoking among females.
The data above shows us that a greater percentage of newly diagnosed diabetes patients came from urban environment in $2016(52.85 \%$ vs. $47.15 \%)$ and in 2017 (50.84\% vs $49.16 \%)$.

However we must mention that in Bihor County according to the yearly report form the County`s Public Health Direction in 2016 $51.42 \%$ of the county's population came from urban environment. This data suggests that in our county distribution of diabetes cases according to environment is almost similar in urban and rural environment. Diabetes is diagnosed predominately in the 


\begin{tabular}{|c|c|c|c|}
\hline BMI & 2016 & 2017 & $2016+2017$ \\
\hline Normal weight & $12.78 \%$ & $10.45 \%$ & $11.615 \%$ \\
\hline Overweight & $35.21 \%$ & $32.62 \%$ & $33.915 \%$ \\
\hline Obese & $52.01 \%$ & $56.93 \%$ & $54.470 \%$ \\
\hline \multicolumn{2}{|r}{} \\
\hline
\end{tabular}

Table nr. 5. Patients' distribution according to BMI

\begin{tabular}{|c|c|c|}
\hline Family history of diabetes & 2016 & 2017 \\
\hline Positive & $35.70 \%$ & $34.20 \%$ \\
\hline Negative & $64.30 \%$ & $65.80 \%$ \\
\hline
\end{tabular}

Tabel nr. 6. Patients' distribution according to family history of diabetes

\begin{tabular}{|c|c|c|c|}
\hline Microvascular complications & 2016 & 2017 & $2016+2017$ \\
\hline Diabetic retinopathy & $7.50 \%$ & $7.32 \%$ & $7.41 \%$ \\
\hline Diabetic polyneuropathy & $24.52 \%$ & $27.68 \%$ & $26.10 \%$ \\
\hline Chronic kidney disease & $17.80 \%$ & $16.45 \%$ & $17.13 \%$ \\
\hline Macrovascular complications & & & \\
\hline Myocardial infarction & $2.92 \%$ & $3.02 \%$ & $2.97 \%$ \\
\hline Ischemic heart disease & $18.54 \%$ & $18.94 \%$ & $18.74 \%$ \\
\hline Stroke & $3.73 \%$ & $3.27 \%$ & $3.50 \%$ \\
\hline Peripheral artery disease & $4.15 \%$ & $4.62 \%$ & $4.39 \%$ \\
\hline
\end{tabular}

Table nr. 7. Microvascular and macrovascular complications in the newly diagnosed patients with diabetes mellitus 


\section{Original papers}

46-65 years group representing $57.35 \%$ of the total patients. This group of population represents active people; diabetes type II is a condition that significantly impacts the quality of life of this population, the chronic complications like myocardial infarction, stroke, chronic peripheral artery disease, retinopathy, and neuropathy lead to a decreased work productivity and early retirement.

Obesity is significantly associated with development of type II diabetes in Bihor County, in 2016 and $201754.47 \%$ of the newly diagnosed patients were obese. These data confirms once more the negative impact of excess body fat on metabolic status, obesity being, as demonstrated by numerous studies probably the most important independent risk factor of diabetes type II, hypertension, hyperuricemia, fatty liver disease and metabolic syndrome ${ }^{(7)}$.

The percent of patients with a postitive family history of diabetes was $35.70 \%$ in 2016 and $34.20 \%$ in 2017. These data support the idea of diabetes type II as a disease with an important genetic component that results as an interaction between genetic factors and environment factors. Recent studies demonstrated that a positive family of diabetes represents an important non-modifiable risk factor for coronary heart disease and metabolic syndrome, leading to the idea that certain genes, more specifically their polymorphism, are responsible for an altered endothelial response $^{(6)}$.

Microvascular complications of diabetes are present from the time of diagnosis, the most frequent being diabetic polyneuropathy in $26.10 \%$, with the observation that the screening of the complications was made in only $35.40 \%$ of the total number of patients. The presence of complications from diagnosis is not a surprise considering the fact that vascular damage and peripheral nerves damage is present even in patients with prediabetes, most probably because of the presence of advanced glycolisation end products $^{(8)}$. Macrovascular complications cannot be attributed only to diabetes because the patients were newly diagnosed; the presence of macrovascular complications is attributed to obesity, hypertension, smoking and dyslipidemia ${ }^{(7)}$.

Risk factors commonly associated with cardiovascular disease are present in a high proportion of patients as shown in fig. 3 . The immediate observation is that all the above risk factors are modifiable; in diabetes type II intensive treatment is necessary not only addressing high blood glucose, but also hypertension, cessation of smoking, increasing physical activity, weight loss and statin treatment. These patients are at great risk for clinical manifested cardio-vascular events with great morbidity and mortality. 


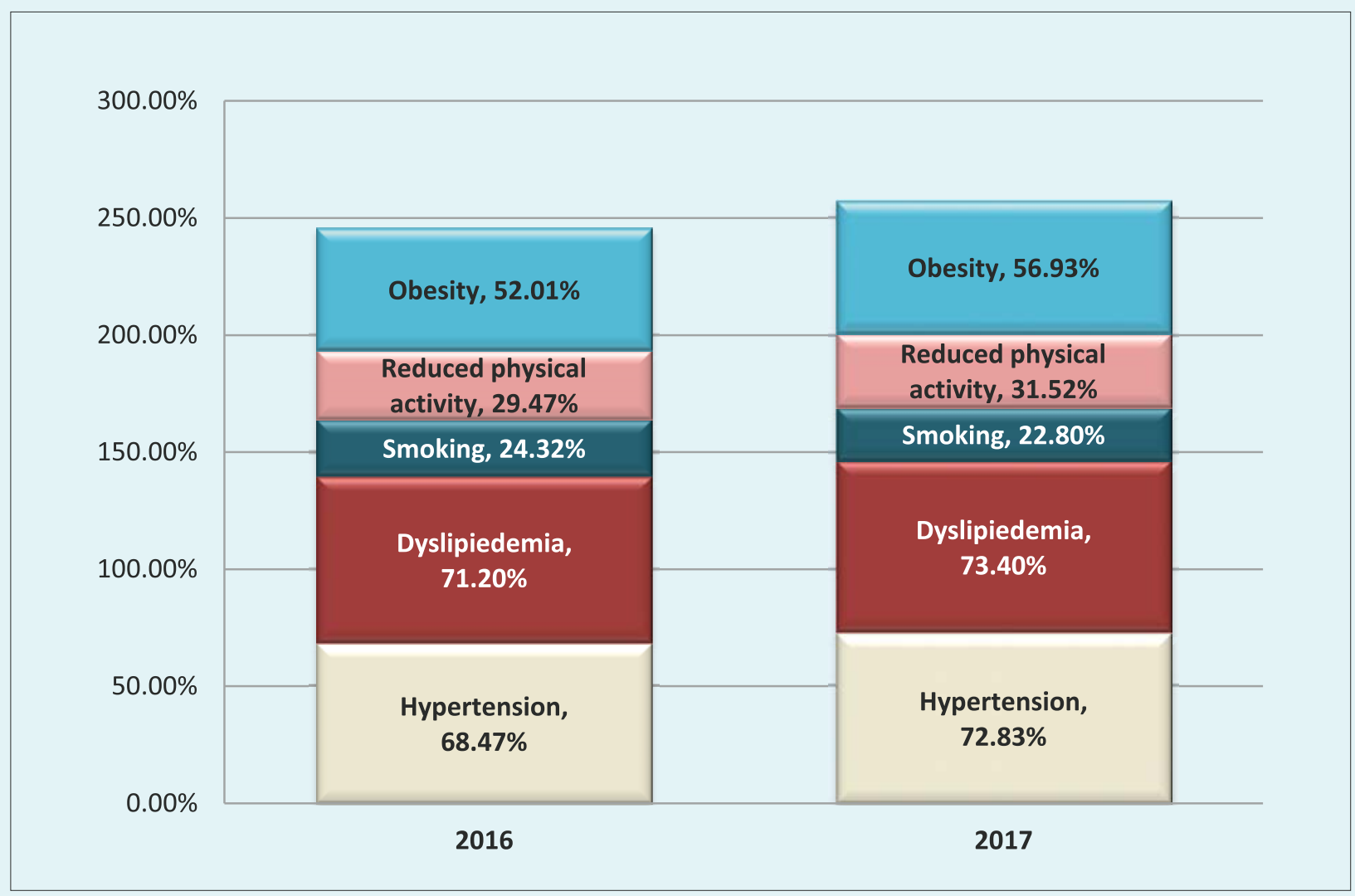

Figure nr. 4. Traditional cardio-vascular risk factor in the patients newly diagnosed with diabetes mellitus

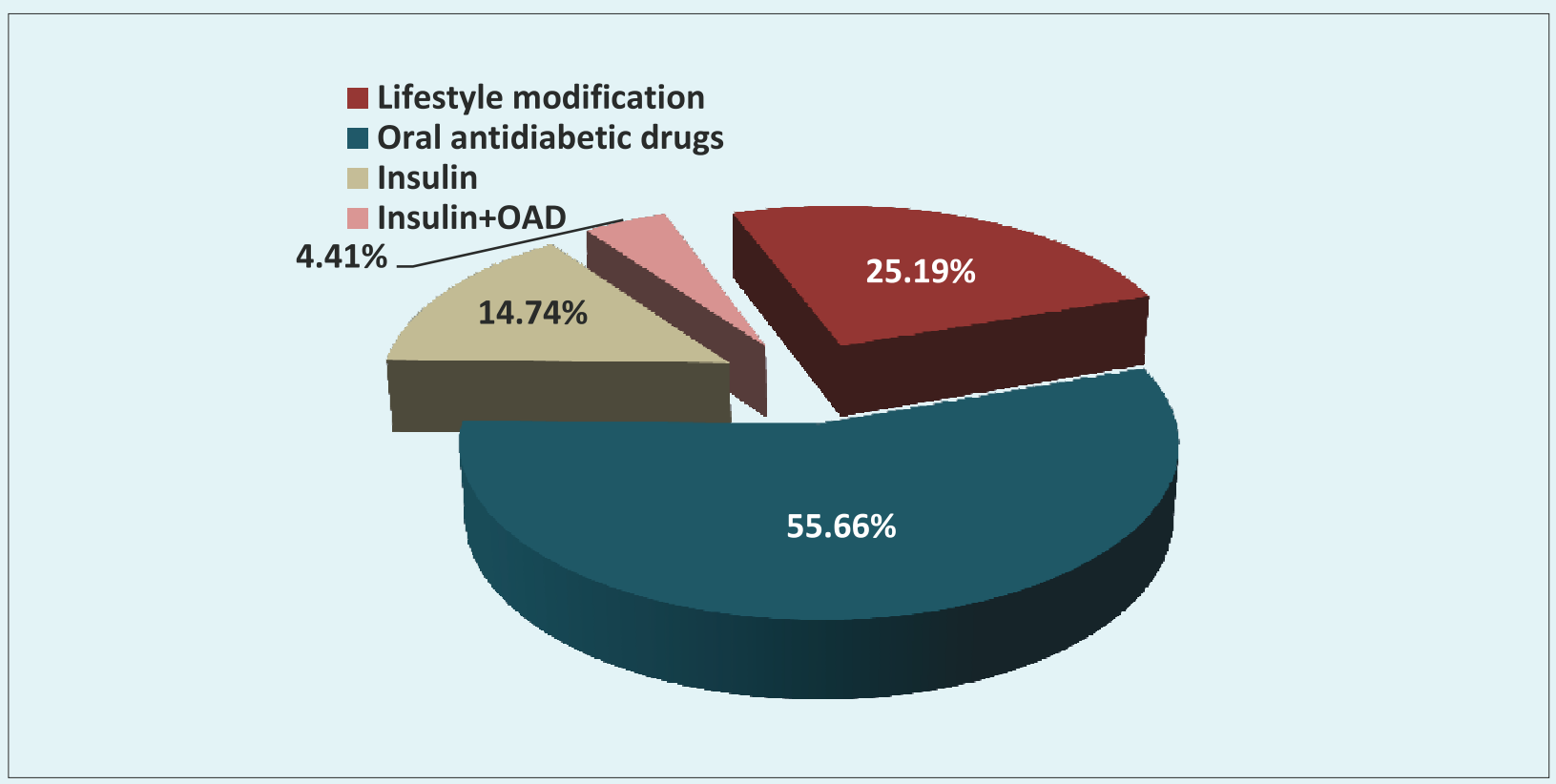

Figure nr. 5. Diabetes therapy in newly diagnosed patients 


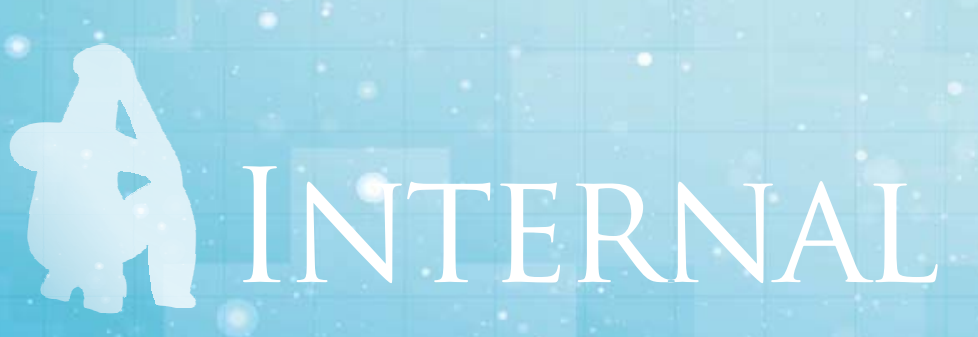

\section{Original papers}

Ten year cardio-vascular disease risk can be assessed in an accurate manner, in our opinion, using UKPDS score because this score takes into account glycated hemoglobin, hypertension, cholesterol, smoking status and also the duration of diabetes. The greatest percent of patients (55.66\%) were given oral antidiabetic drugs, as shown in figure 4 . The preferred antidiabetic was mostly metformin followed by sulfonylureas. Metformin decreases insulin resistance, the most desirable manner of action in a population with excess weight; also studies support the protective role of metformin for the cardiovascular function and in the lipid metabolism.

\section{Conclusions}

In Bihor County the incidence of diabetes in year 2016 was 3451 cases and in 2017 was 2705 cases, further observation in the next years need to be done to confirm or infirm a descendent trend. The prevalence of diabetes in Bihor County has increased from $4.71 \%$ of total population in 2011 to $5.24 \%$ in 2016 . Data from diabetic registers seem to massively underestimate the prevalence of diabetes, cross sectional studies like PREDATORR showing prevalence almost double than the studies performed from diabetes registers. In Bihor diabetes is more common in females than in males, in urban environment than in rural environment and in the age group 47-65 years. Patients with diabetes are in great majority obese or overweight, and the presence of cardio-vascular risk factor like hypertension, dyslipidaemia, physical inactivity or smoking is common. Lifestyle modification and intensive treatment of all risk factors not only hyperglycaemia are a requirement for reducing the excess morbidity and mortality of this population.

\section{References}

1. Moța M, Dinu I.R, The Analysis Of Prevalence And Incidence Of Diabetes Mellitus In Romania, Rom J Diabetes Nutr Metab Dis. 20(2):135-139

2. Moța M, Popa SG, Mota E, Mitrea A, Catrinoiu D, Prevalence of diabetes mellitus and prediabetes in the adult Romanian population: PREDATORR study, J Diabetes. 2016 May; 8(3):336-44

3. Kautzky-Willer A, Harreiter, J, Sex and Gender Differences in Risk, Pathophysiology and Complications of Type 2 Diabetes Mellitus, Endocr Rev. 2016 Jun; 37(3): 278316

4. O'Connor A1, Wellenius G., Rural-urban disparities in the prevalence of diabetes and coronary heart disease, Public Health. 2012 Oct;126(10):813-20

5. Public Activity Report Of Bihor's County Public Health Direction On Year 2016

6. Hariri S, Yoon PW, Qureshi N, Valdez R, Scheuner MT, Khoury MJ., Family history of type 2 diabetes: a populationbased screening tool for prevention?, Genet Med. 2006 Feb;8(2):102-8.

7. Michael J. Fowler, Microvascular and Macrovascular Complications of Diabetes, Clinical Diabetes 2008 Apr; 26(2): 77-82

8. Huang Y, Cai X, Mai W, Li M, Hu Y, Association between prediabetes and risk of cardiovascular disease and allcause mortality: systematic review and meta-analysis, BMJ. 2016 Nov 23;355 